\title{
Effects of different crop years and sowing date on maize yield
}

\author{
Gergő Sedlák - Adrienn Széles \\ University of Debrecen Faculty of Agricultural and Food Sciences and Environmental Management, \\ Institute for Land Utilisation, Technology and Regional Development, Debrecen \\ szelesa@agr.unideb.hu
}

SUMMARY

We carried out the tests in the flood meadow soil formed on the alluvial cone of Nagykereki, Sebes-Körös belonging to the Bihar plane small region. The aim of the study was to analyse the effect of the different sowing date of maize on the yield trend based on a comprehensive study conducted for 6 years (2007-2012).

The sowing date of maize hybrids is a factor that significantly influences yield, however, its effect is not significant in each crop year. In the years when the date of sowing has a modifying effect, the reliable yield level can be reached with optimal sowing date management (24 April).

The advantage of early sowing (10 April) proved to be dominant in the year of 2012, the seeds were placed into the still wet soil therefore shooting was more balanced. Maize seeds sown at the time of optimal (24 April) and late (10 May) sowing dates were placed into the already dry soil, which deteriorated germination and the strength of early initial development that had an effect on the yield.

Keywords: crop year, sowing date, maize

\section{ÖSSZEFOGLALÁS}

A vizsgálatokat a Bihari-sik kistájhoz tartozó Nagykereki, Sebes-Körös hordalékkúpján kialakult öntés réti talajon végeztük. A dolgozat célja volt, a kukorica eltérö vetésidejének hatásvizsgálata a termés alakulására 6 év (2007-2012) átfogó vizsgálata alapján.

A kukoricahibridek vetésideje jelentös termés befolyásoló tényezö, hatása azonban nem minden évjáratban szignifikáns. Azokban az években, ahol a vetés idöpontjának módositó hatása van a megbizható termésszint az optimális (április 24.) vetésidö-kezelésben érhetö el.

A korai (április 10.) vetés elönye a 2012-es évben mutatkozott dominánsnak, a vetömag még nedves talajba került, ezért a kelés egyenletesebb volt. Az optimális (április 24.) és a késői (május 10.) vetéskor elvetett kukorica már száraz talajba került, rontva ezzel a csírázását és a korai kezdeti fejlödési erélyét, ami hatással volt a termésre.

Kulcsszavak: évjárat, vetésidö, kukorica

\section{INTRODUCTION}

In order to select the best sowing date for maize, the climate, the quality, position, temperature, weediness of the soil, the quality of seeds, as well as the growing season of the hybrid to be grown shall be taken into consideration. In the case of a deviation from the optimal date of maize sowing (25-26 April) (no matter whether it is early or late sowing) a yield decrease should be expected (Sárvári and Futó, 2000; Berzsenyi and Dang, 2001; Nagy, 2009; Ványiné et al., 2010; Soledad et al., 2013).

The germination temperature of maize varies between 8 and $12^{\circ} \mathrm{C}$, Marton (1991) considers the temperature range between 9 and $18{ }^{\circ} \mathrm{C}$ optimal. At a low soil temperature, the vitality of maize considerably reduces (Miedema, 1982). According to Anderejko and Kuperman (1961) germination starts already at $6{ }^{\circ} \mathrm{C}$, however, germination lasts longer at low soil temperature thus maize grains are exposed to the different pests living in the ground, and to fungal diseases. Mándy (1958) says that at a soil temperature of $21^{\circ} \mathrm{C}$ shooting happens 5 6 days after sowing, whereas at $16-18{ }^{\circ} \mathrm{C}$ it happens after 8-10 days. In medium hard clayey soil, favourable soil temperature at a depth of $5-10 \mathrm{~cm}$ may be $10^{\circ} \mathrm{C}$, in clay soils it may be $1-2^{\circ} \mathrm{C}$ higher, and in sandy soils it may be $1-2{ }^{\circ} \mathrm{C}$ lower (Newmann, 1982). A $1{ }^{\circ} \mathrm{C}$ change in soil temperature already has an effect on the development of the plant (Walker, 1969; Barlow et al.,
1977; Stone et al., 1999). Mozafar et al. (1993) reported the stagnating growth of maize if the root zone has a low temperature $\left(9^{\circ} \mathrm{C}\right)$, this low soil temperature hinders the growth of the leaf surface (Thiagarajah and Hunt, 1982), the flowering (Cutforth and Shaykewich, 1989; Hayhoe and Dwyer, 1990; Hayhoe et al., 1996), and the formation of black layer (Keszthelyi, 2005).

The aim of the set experiment is to analyse the effect of the different sowing date of maize on the yield trend based on a comprehensive study conducted for 6 years (2007-2012).

\section{MATERIAL AND METHODS}

We carried out the tests in the flood meadow soil formed on the alluvial cone of Nagykereki, SebesKörös belonging to the Bihari plane small region. The $45 \mathrm{~m}^{2}$ lots were formed in the operation area, in a random block design, in 4 repetitions. We followed the growing technology that is generally used in practice. The green crop was maize in each year. The fertilizer active substances used in the area were $150 \mathrm{~kg} \mathrm{~N} \mathrm{ha}^{-1}, 65 \mathrm{~kg}$ $\mathrm{P}_{2} \mathrm{O}_{4} \mathrm{ha}^{-1}$ and $130 \mathrm{~kg} \mathrm{~K}_{2} \mathrm{O} \mathrm{ha} \mathrm{h}^{-1} .50 \%$ of the $34 \%$ ammonium-nitrate quantity was introduced into the soil in autumn, $50 \%$ of it was introduced before the seed bed preparation in spring, whereas phosphorus and potassium were introduced in $100 \%$ during the autumn basic cultivation. Sowing at the early (10 April), optimal (24 April) and late (10 May) dates happened in 
a unified manner, each with a stem number of 70 thousand stems/ha. In the subsequent years hybrids belonging to the same maturity group (FAO 200, FAO 300 and FAO 400) were involved. Harvesting of the experiment happened in the first two weeks of October in each year. The harvested grain crop was given with a humidity content of $14 \%$.

Soil: It has the mechanical composition of adobe clay, it is flood meadow soil. The average $\mathrm{pH}_{\mathrm{KCl}}$ value of the cultivated layer is 6.1 (weakly acidic chemical effect), Arany-type compactness value is 40 , hygroscopicity is $2.8 \%$. Organic material quantity is between $2-3 \%$, AL-soluble $\mathrm{P}_{2} \mathrm{O}_{5}$ is $150 \mathrm{mg} \mathrm{kg}^{-1}$, AL-soluble $\mathrm{K}_{2} \mathrm{O}$ is $195 \mathrm{mg} \mathrm{kg}^{-1}$. Ground water varies between 3 and $4 \mathrm{~m}$. Its fertility class is $45-60$ (int) ground quality category.

Weather: Weather was evaluated based on the data measured by the simple instruments (vapour content measuring device, precipitation measuring device, max-min temperature thermometer) placed in the area of the experiment. Based on the quantity of precipitation that fell in the growing season, the effective heat sum, and the potential evapotranspiration values, homogeneous groups were formed by means of hierarchical cluster analysis. The years could be classified as follows: dry, droughty years: 2007 and 2012, dry years: 2009, rainy years: 2008 and 2010, favourable, average years: 2011 (Figure 1).

Statistical evaluation: For the assessment of the effects exercised on the yield by the treatments a general linear model (GLM) was used. For the comparison of treatment mean values, 5\% significant difference $\left(\mathrm{LSD}_{5 \%}\right)$ was determined, as well as homogeneous groups were formed by means of multiple mean values comparison test, with the Duncan method. The yields within the homogeneous group do not differ from one another in the case of a significance level of 5\%. The evaluation was prepared with the use of the SPSS for Windows 13.0 statistical programme package.

Figure 1: Precipitation and temperature trends in the growing season (Nagykereki, 2007-2012)

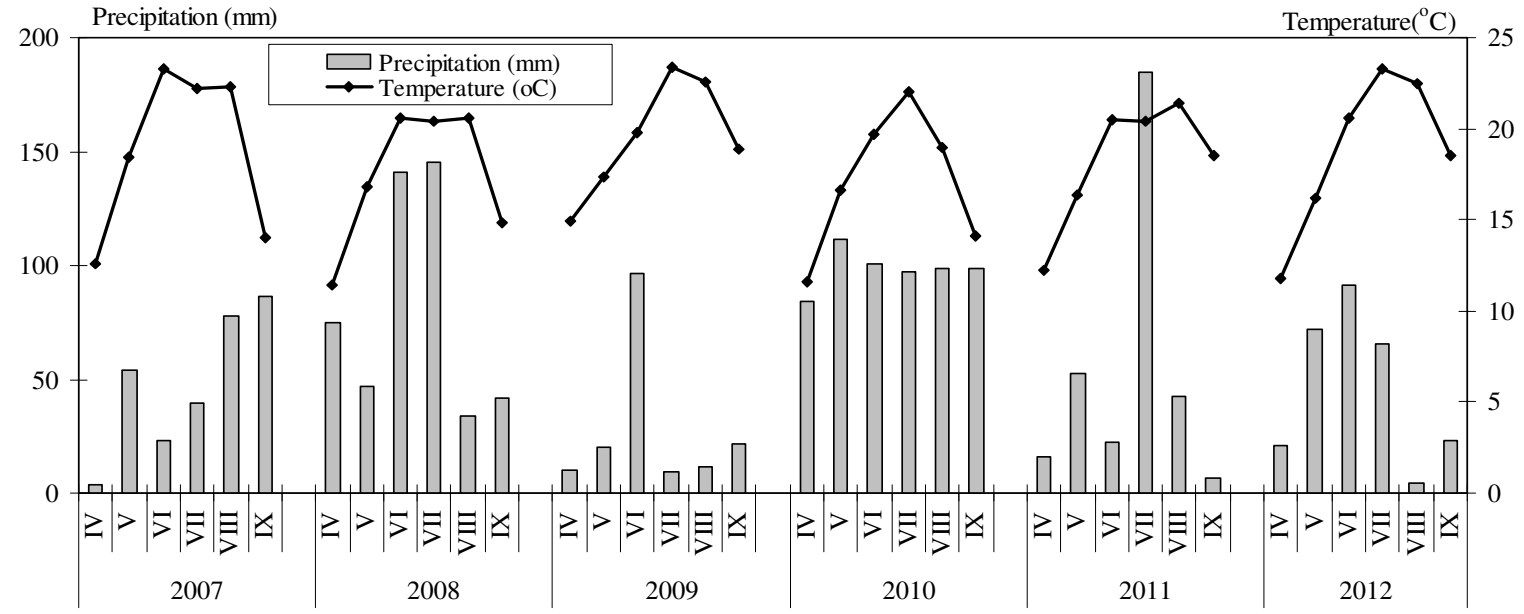

\section{RESULTS}

The variance analysis of the two-factorial, random block experiment design was carried out for the grain crop by years (Table 1). Based on the mean square deviation (MQ) values, the date of sowing had the most significant effect among the factors in the years 2010 , 2011 and 2012, whereas in the years 2008 and 2009 the effect of sowing date is not proved statistically. The difference among the hybrids proved to be statistically reliable in each year: $0.1 \%(2007,2008,2012), 1 \%$ (2009) and 5\% $(2010,2011)$. The hybrid $\times$ sowing time interaction was significantly detectable in 2007.

In the year 2007 the average yield of the hybrids was the greatest at the optimal sowing time with the Duncan-type test and at a significance level of $5 \%$ $\left(6.521 \mathrm{tha}^{-1}\right)$. The grain crop of the late sowing was by $1087 \mathrm{~kg} \mathrm{ha}^{-1}$, the grain crop of the early sowing was by $840 \mathrm{~kg} \mathrm{ha}^{-1}$ greater. The yield of early sowing was not significantly greater $\left(5.681 \mathrm{t} \mathrm{ha}^{-1}\right)$ than that of the late sowing (5.434 t ha-1). In the years 2008 and 2009 the sowing dates did not influence the yield trends. In
2010 the optimal sowing date proved to be successful $\left(9.251 \mathrm{tha}^{-1}\right)$, its extra yield compared to the early sowing was $1223 \mathrm{~kg} \mathrm{ha}^{-1}$. There was no significant deviation between the optimal and late sowing. In the crop year of 2011 the yield result of the early sowing was considerably (by $1883 \mathrm{~kg} \mathrm{ha}^{-1}$ ) less than that of optimal sowing. The yield of optimal sowing was not significantly greater $\left(11.083 \mathrm{t} \mathrm{ha}^{-1}\right)$ than that of the late sowing $\left(11.678 \mathrm{t} \mathrm{ha}^{-1}\right)$. In 2012 hybrids reached their greatest average yield (12.533 tha-1) with the early sowing date, it resulted in a $17.7 \%$ increase of the yield compared to the optimal sowing $\left(10.650 \mathrm{t} \mathrm{ha}^{-1}\right)$. The late sowing reduced their yields $\left(10.283 \mathrm{tha}^{-1}\right)$, compared to the early sowing the yield loss was $21.9 \%$. The reduction between the optimal and late sowing was $3.6 \%$, which is statistically not reliable (Table 2).

Regarding the yields quantified by the crop years - by the average of the hybrids and sowing dates - no difference could be detected based on the LSD test between the yields of 2008 and 2010, and between the yields of 2009 and 2012 (Figure 2). 
Table 1 .

The variance analysis result of the effect of sowing date and hybrid yield (t ha-1) (Nagykereki, 2007-2012)

\begin{tabular}{|c|c|c|c|}
\hline Factors & MQ & DF & F-value \\
\hline \multicolumn{4}{|l|}{2007} \\
\hline Sowing date $[\mathrm{A}]$ & 3.893 & 2 & $11.863^{* * *}$ \\
\hline Hybrid [B] & 7.957 & 2 & $24.245^{* * *}$ \\
\hline $\mathrm{A} \times \mathrm{B}$ & 0.969 & 4 & $2.953^{*}$ \\
\hline \multicolumn{4}{|l|}{2008} \\
\hline Sowing date $[\mathrm{A}]$ & 0.015 & 2 & $0.041^{\mathrm{ns}}$ \\
\hline Hybrid [B] & 8.271 & 2 & $22.411^{\text {*** }}$ \\
\hline $\mathrm{A} \times \mathrm{B}$ & 0.357 & 4 & $0.967^{\mathrm{ns}}$ \\
\hline \multicolumn{4}{|l|}{2009} \\
\hline Sowing date $[\mathrm{A}]$ & 2.649 & 2 & $3.254^{\mathrm{ns}}$ \\
\hline Hybrid [B] & 5.166 & 2 & $6.347^{* *}$ \\
\hline $\mathrm{A} \times \mathrm{B}$ & 1.530 & 4 & $1.880^{\mathrm{ns}}$ \\
\hline \multicolumn{4}{|l|}{2010} \\
\hline Sowing date $[\mathrm{A}]$ & 6.028 & 2 & $5.711^{* *}$ \\
\hline Hybrid [B] & 3.680 & 2 & $3.487^{*}$ \\
\hline $\mathrm{A} \times \mathrm{B}$ & 1.599 & 4 & $1.514^{\mathrm{ns}}$ \\
\hline \multicolumn{4}{|l|}{2011} \\
\hline Sowing date $[\mathrm{A}]$ & 60.452 & 2 & $40.330^{* * * *}$ \\
\hline Hybrid [B] & 7.205 & 2 & $4.807^{*}$ \\
\hline $\mathrm{A} \times \mathrm{B}$ & 3.321 & 4 & $2.216^{\mathrm{ns}}$ \\
\hline \multicolumn{4}{|l|}{2012} \\
\hline Sowing date $[\mathrm{A}]$ & 17.488 & 2 & $23.045^{* * *}$ \\
\hline Hybrid [B] & 10.339 & 2 & $13.624^{* * * *}$ \\
\hline $\mathrm{A} \times \mathrm{B}$ & 1.642 & 4 & $2.163^{\mathrm{ns}}$ \\
\hline
\end{tabular}

Note: ***Significant at $\mathrm{P}=0.1 \%$ level,**Significant at $\mathrm{P}=1 \%$ level,

*Significant at $\mathrm{P}=5 \%$ level, $\mathrm{ns}=$ non-significant.

The effect of sowing date on the yield $\left(\mathrm{t} \mathrm{ha}^{-1}\right)$ (Nagykereki, 2007-2012)

\begin{tabular}{lrcr}
\hline \multirow{2}{*}{ Years } & \multicolumn{3}{c}{ Sowing date } \\
\cline { 2 - 4 } & Early & Optimal & Late \\
\hline 2007 & $5.681 \mathrm{a}$ & $6.521 \mathrm{~b}$ & $5.434 \mathrm{a}$ \\
2008 & $8.409 \mathrm{a}$ & $8.392 \mathrm{a}$ & $8.285 \mathrm{a}$ \\
2009 & $10.758 \mathrm{a}$ & $11.667 \mathrm{a}$ & $11.421 \mathrm{a}$ \\
2010 & $8.028 \mathrm{a}$ & $9.251 \mathrm{~b}$ & $9.262 \mathrm{~b}$ \\
2011 & $7.526 \mathrm{a}$ & $11.083 \mathrm{~b}$ & $11.678 \mathrm{~b}$ \\
2012 & $12.533 \mathrm{a}$ & $10.650 \mathrm{~b}$ & $10.283 \mathrm{~b}$ \\
\hline
\end{tabular}

Note: the data indicated by identical letters within one row do not differ significantly from one another based on the Duncan test.
Figure 2: The effect of crop year on the maize yield (Nagykereki, 2007-2010)

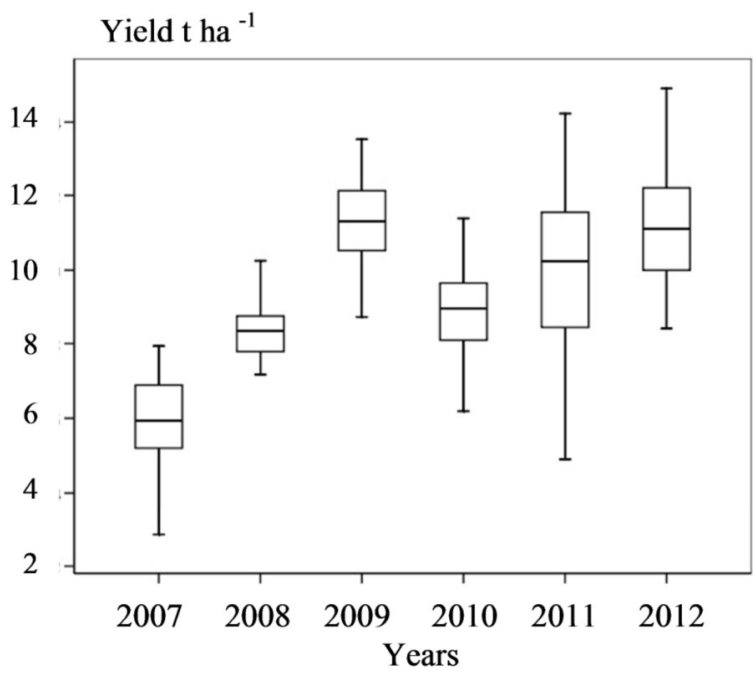

\section{CONCLUSIONS}

In the average of six years all the three factors (sowing date, hybrid, crop year) reliably influenced $(\mathrm{P}<0.001)$ the maize yield. Based on the MQ value, the effect of the year was the most significant, which shows that from the aspect of the yield the crop years meant greater environmental variance than the different sowing dates within the year. The sowing date $\times$ year $(\mathrm{P}<0.001)$ and year $\times$ hybrid $(\mathrm{P}<0.05)$ interactions were significant, whereas the sowing date $\times$ hybrid interaction did not influence the examined parameter.

\section{REFERENCES}

Anderejko, Sz. Sz.-Kuperman, F. M. (1961): A kukorica élettana. Mezőgazdasági Kiadó. Budapest.

Barlow, E. W. R.-Boersma, L.-Young, J. L. (1977): Photosynthesis, transpiration, and leaf elongation in corn seedlings at suboptimal soil temperatures. Agron. J. 69: 95-100.

Berzsenyi Z.-Dang, Q. L. (2001): A vetésidő és a N-mütrágyázás hatása a kukorica- (Zea mays L.) hibridek termésére és termésstabilitására 1991 és 2000 között. Növénytermelés. 50: 309-331.

Cutforth, H. W.-Shaykewich, C. F. (1989): Relationship of development rates of corn from planting to silking to air and soil temperature and to accumulated thermal units in a prairie environment. Can. J. Plant Sci. 69: 121-132

Hayhoe, H. N.-Dwyer, L. M.-Stewart, D. W.-White, R. P.-Culley, J. L. B. (1996): Tillage, hybrid and thermal factors in corn establishment in cool soils. Soil Tillage Res. 40: 39-54.
Hayhoe, H. N.-Dwyer, L. M. (1990): Relationship between percentage emergence and growing degree days for corn. Can. J. Soil Sci. 70: 493-497.

Keszthelyi S. (2005): A 2004. év klimatikus tényezőinek hatása a kukorica fejlődésére, kártevőinek megjelenésére és kártételére. Agrofórum Extra. 10: 3-7.

Mándy Gy. (1958): Ökológiai vizsgálatok kukoricafajtákkal. [In: I'só I. (szerk.) Kukoricatermesztési kísérletek 1953-1957.]. Akadémiai Kiadó. Budapest. 91-105.

Marton L. Cs. (1991): Kukorica beltenyésztett törzsek kelése és kezdeti fejlődése hőmérséklet gradiens kamrában. II. A beltenyésztett törzsek kezdeti fejlődése. Növénytermelés. 40: 1-10.

Miedema, P. (1982): The effects of low temperature on Zea mays. Advances in Agronomy. 35: 93-128. 
Mozafar, A.-Schreiber, P.-Oertli, J. J. (1993): Photoperiod and rootzone temperature: interacting effects on growth and mineral nutrients of maize. Plant and Soil. 153: 71-78.

Nagy J. (2009): A vetésidő hatása a kukorica- (Zea mays L.) hibridek terméshozamára és minőségére. Növénytermelés. 58. 2: 85-105.

Newmann, J. E. (1982): Tips on timing corn planting. Farmer's Digest. Milwaukee. 45. 8: 5-8.

Sárvári M.-Futó Z. (2000): Összefüggés a kukoricahibridek vetésideje, produkciója és a betakarításkori nedvességtartalma között csernozjom talajon. Debreceni Egyetem. Agrártudományi Közlemények. 1: 32-41.

Soledad V. L.-Blanco, M.-Cortada, L.-Sorribas, F. J. (2013): Resistance of tomato rootstocks to Meloidogyne arenaria and Meloidogyne javanica under intermittent elevated soil temperatures above $28^{\circ} \mathrm{C}$. Crop Protection. 46: 57-62.
Stone, P. J.-Sorensen, I. B.-Jamieson, P. D. (1999): Effect of soil temperature on phenology, canopy development, biomass and yield of maize in a cool-temperate climate. Field Crops Research. 63: 169-178

Thiagarajah, M. R.-Hunt, L. A. (1982): Effects of temperature on leaf growth in corn (Zea mays L.). Can. J. Bot. 60: 1647-1652.

Ványiné Széles A.-Megyes A.-Nagy J. (2010): A vetésidő és az évjárat hatása a kukorica- (Zea mays L.) hibridek terméshozamára és minőségére. Növénytermelés. 59. 4: 63-88.

Walker, J. M. (1969): One-degree increments in soil temperatures affect maize seedling behavior. Soil Sci. Soc. Am. Proc. 33: 729-736. 